\title{
A trans-Holocene archaeological record of Guadalupe fur seals (Arctocephalus townsendi) on the California coast
}

TORBEN C. RicK

Department of Anthropology,

National Museum of Natural History,

Smithsonian Institution,

Washington, DC 20013-7012, U.S.A.

\section{ROBERT L. DeLONG}

National Marine Mammal Laboratory, Alaska Fisheries Science Center, NOAA, Bldg. 4, 7600 Sand Point Way N.E., Seattle, Washington 98115, U.S.A.

JON M. ERLANDSON

Department of Anthropology, and

Museum of Natural and Cultural History,

University of Oregon,

Eugene, Oregon 97403-1218, U.S.A.

TODD J. BRAJE

Department of Anthropology,

Humboldt State University,

Arcata, California 95521, U.S.A.

TERRY L. JONES

Social Sciences Department,

California Polytechnic State University,

San Luis Obispo, California 93407, U.S.A.

Douglas J. KennetT

Department of Anthropology,

University of Oregon,

Eugene, Oregon 97403-1218, U.S.A.

THOMAS A. WAKe

Cotsen Institute of Archaeology,

University of California,

Los Angeles, California 90095-1510, U.S.A.

\section{Phillip L. WALKeR}

Department of Anthropology, University of California, Santa Barbra, California 93106-3210, U.S.A. 
Guadalupe fur seals (Arctocephalus townsendi) were decimated by 19th century commercial sealers in the northeastern Pacific and thought to be extinct until 1928 when commercial fishermen caught two adult males at Isla de Guadalupe from a group of up to 60 adults and pups (Wedgeforth 1928, Huey 1930). These two animals were brought to the San Diego Zoo, prompting several zoological expeditions to Isla de Guadalupe in the 1930s and 1940s, but none successfully located Guadalupe fur seals. In 1949, a single male was seen on San Nicolas Island, California (Bartholomew 1950), and in 1954, a small breeding group of animals was found in a cave at Isla de Guadalupe (Hubbs 1956). The population had grown to at least 500 animals in 1967 , to about 7,400 animals in 1993 , and to 12,176 in 2003 , with breeding populations currently confined to Mexico's Islas de Guadalupe and San Benito (Peterson et al. 1968, Gallo-Reynoso 1994, Gallo-Reynoso et al. 2005, Carretta et al. 2007). Although small numbers of Guadalupe fur seals haul out on the California Channel Islands today, including a female and single pup born on San Miguel Island in 1997, they are vastly outnumbered by California sea lions (Zalophus californianus), northern elephant seals (Mirounga angustirostris), northern fur seals (Callorbinus ursinus), and harbor seals (Phoca vitulina), all of which currently breed on San Miguel Island (Stewart et al. 1993, Melin and DeLong 1999, DeLong and Melin 2002). Archaeological and genetic data suggest, however, that the modern distribution and abundance of Guadalupe fur seals are very different from prehistoric distributions (Walker and Craig 1979, Colten 2002, Etnier 2002a, Walker et al. 2002, Weber et al. 2004).

Because Arctocephalus townsendi was not described as a new species until 1897 after historical commercial sealing had devastated the population, questions remain about its biogeography, natural history, and range (Merriam 1897, Hanni et al. 1997, Melin and DeLong 1999, Etnier 2002a). Although a few fur seals identified in historical accounts from the Farallon Islands were thought to be Guadalupe fur seals, the best estimate of the historical northern range for Guadalupe fur seals is likely the northern Channel Islands (Repenning et al. 1971). Fur seals on the Farallon Islands, which were extirpated by commercial sealers in the early 1800 s, were originally identified as A. townsendi (Starks 1922), and bones from commercial sealing middens were also reported to be $A$. townsendi (Riddell 1955). The bone collection was reexamined by J. Schonwald of the California Academy of Sciences and found to be C. ursinus (Repenning et al. 1971, Pyle et al. 2001). Archaeological data and modern strandings, however, indicate that Guadalupe fur seals at least occasionally occur in northern California, Oregon, and Washington (Lyon 1937:165, Hanni et al. 1997, Etnier 2002a, Moss et al. 2006). In this note, we provide the first synthesis of Guadalupe fur seal remains from archaeological sites in coastal California, supplying information on their past distributions, ecology, natural history, and management (Fig. 1).

We performed a systematic literature review of published accounts of Guadalupe fur seals from California archaeological sites, and also compiled a number of additional identifications from unpublished reports. We were cautious when compiling the archaeological occurrences of Guadalupe fur seals and only included specimens identified by a reputable specialist (see Lyman 2002 for a review). We included 


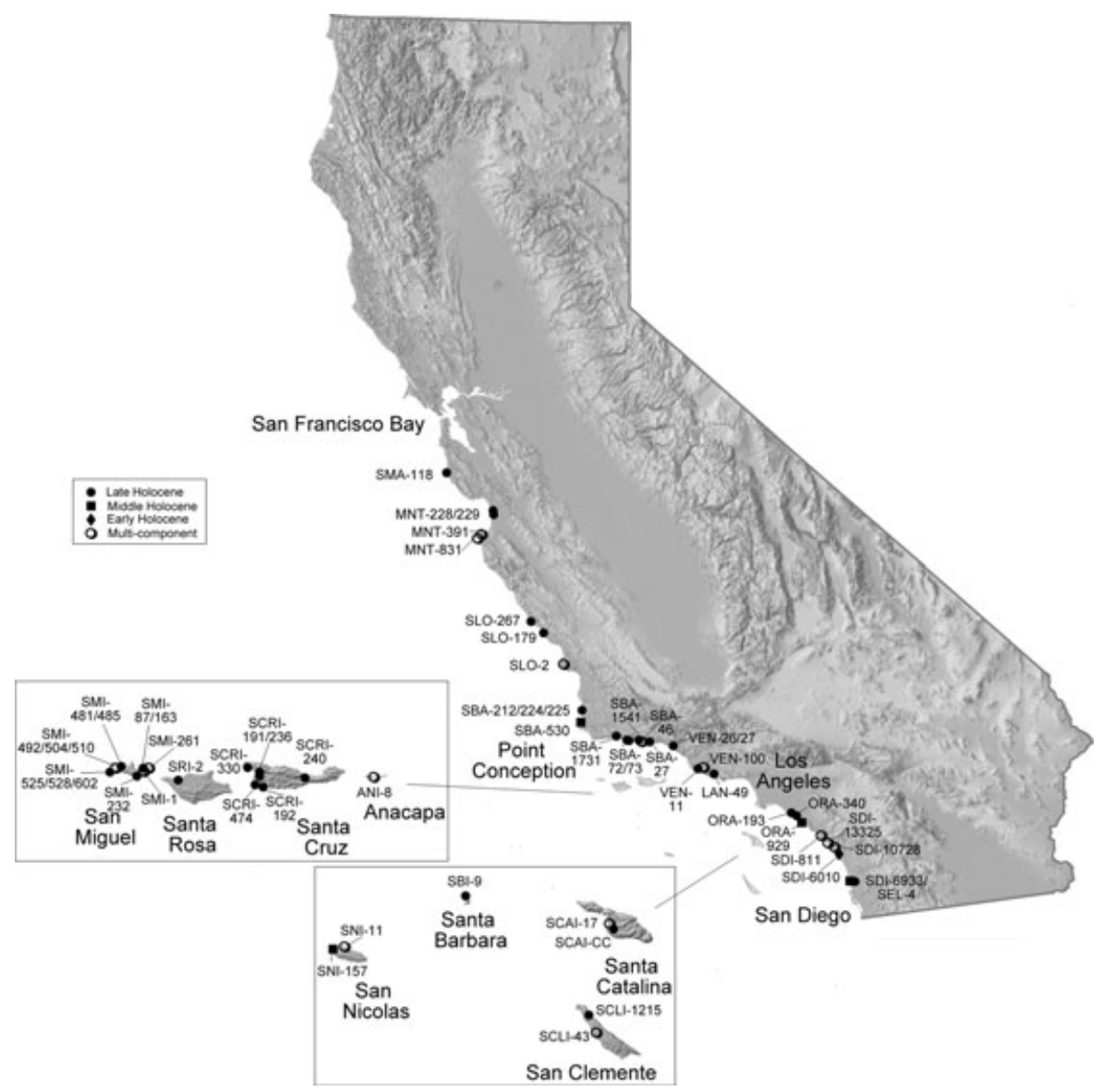

Figure 1. Location of archaeological sites containing Guadalupe fur seal remains in California.

specimens identified to species, excluding those that were identified solely as fur seal. We recorded bone and teeth counts and minimum number of individuals (MNI), an estimate of the total number of animals based on the frequency of non-repetitive elements (Grayson 1984, Lyman 2008). When available, we also included age and sex estimates.

Guadalupe fur seals have been identified in at least 60 archaeological sites on the California Coast, including 32 on the mainland and 28 from the Channel Islands (Table 1). At least 3,478 Guadalupe fur seal bones or teeth have been identified with 1,601 from the Channel Islands and 1,877 from the mainland. Many researchers did not report MNI, but a conservative estimate indicates that there are at least 576 individuals represented: 306 from the islands and 270 from the mainland. San Miguel Island contains 13 sites, the largest concentration in our data set, followed 


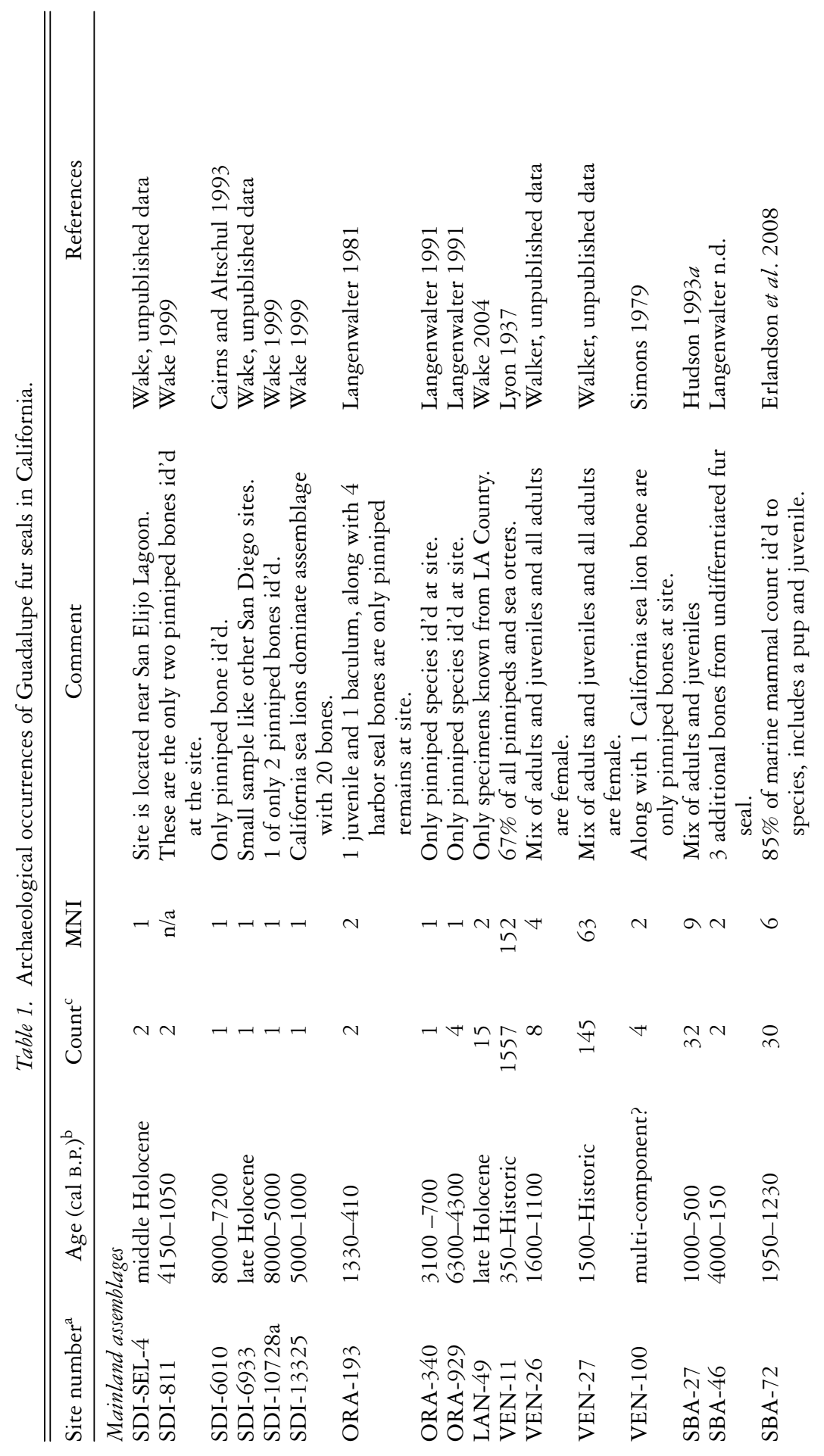




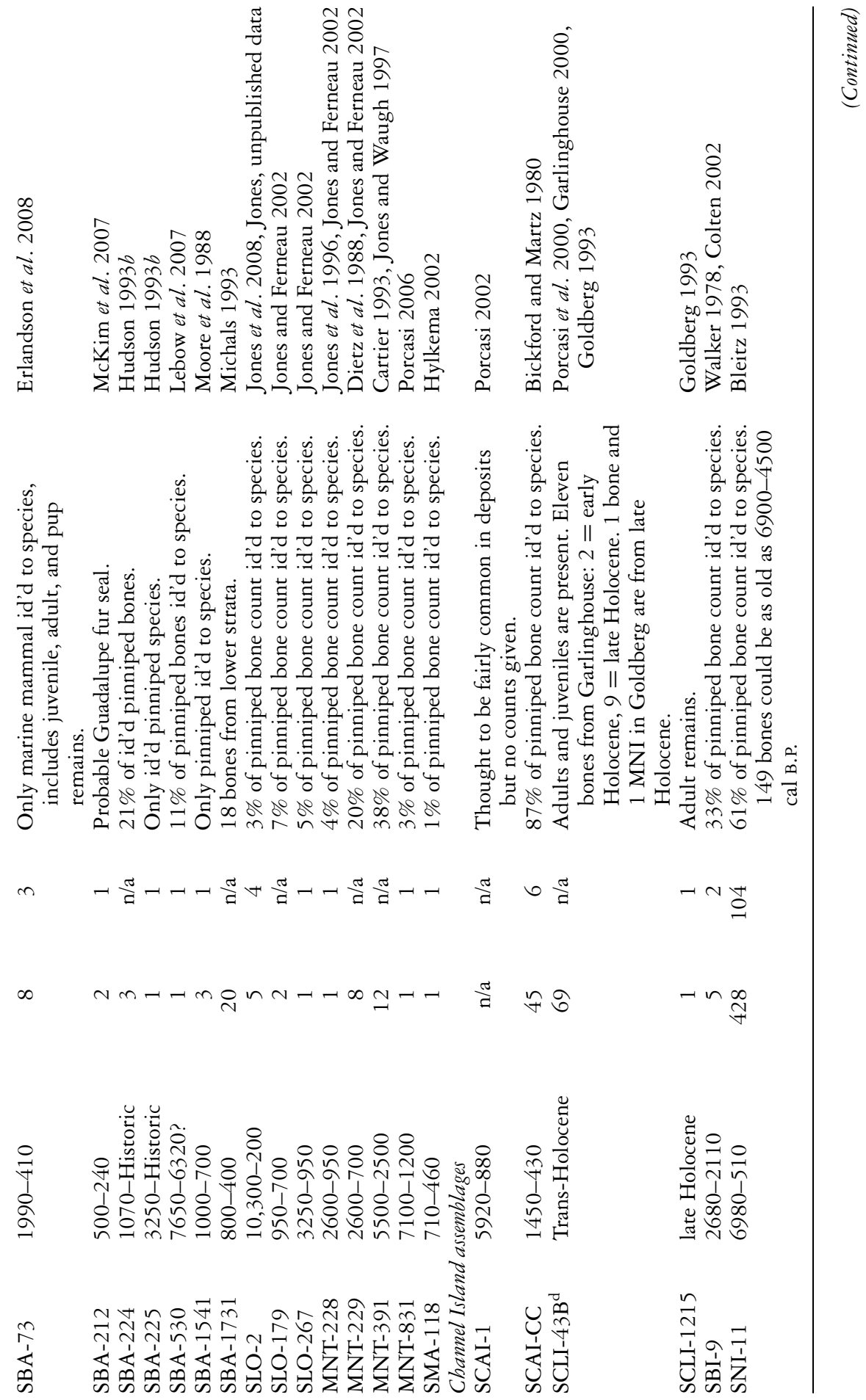




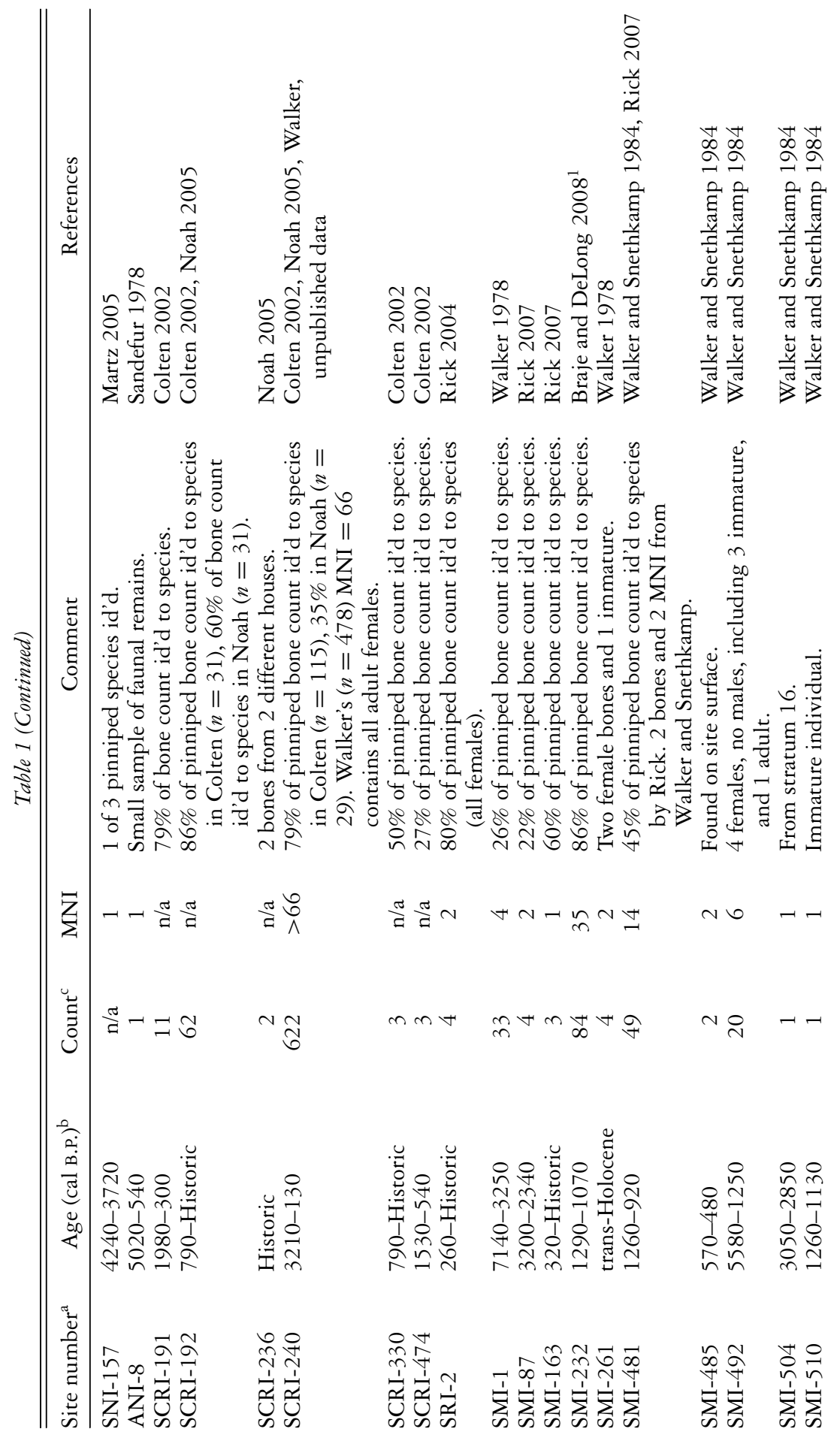




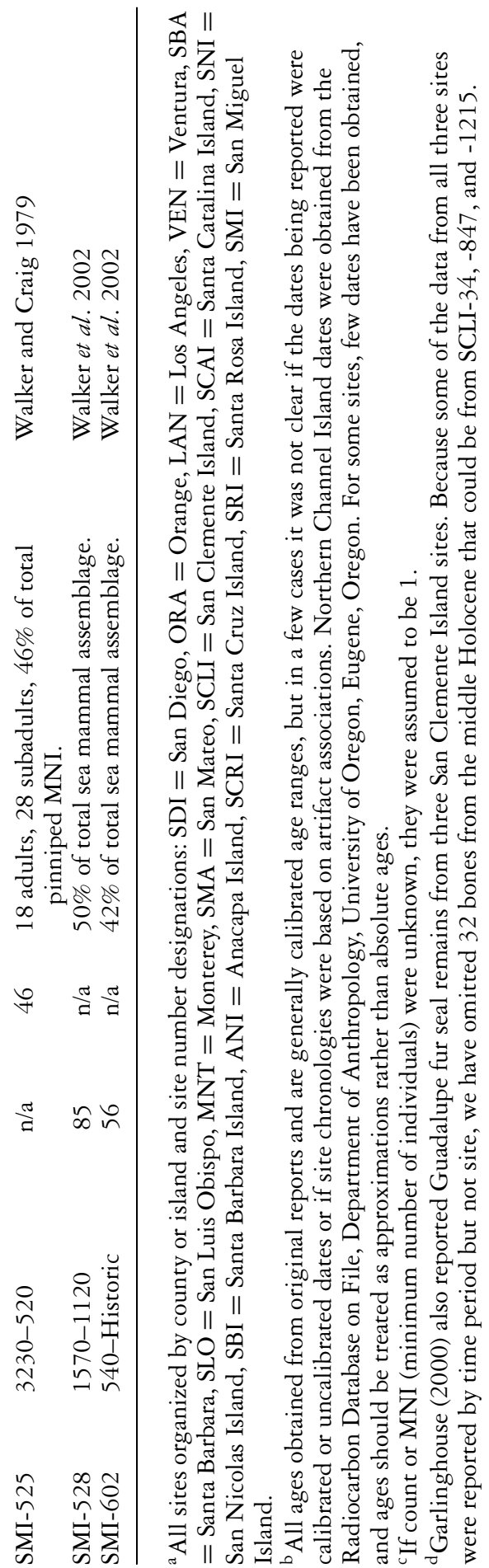




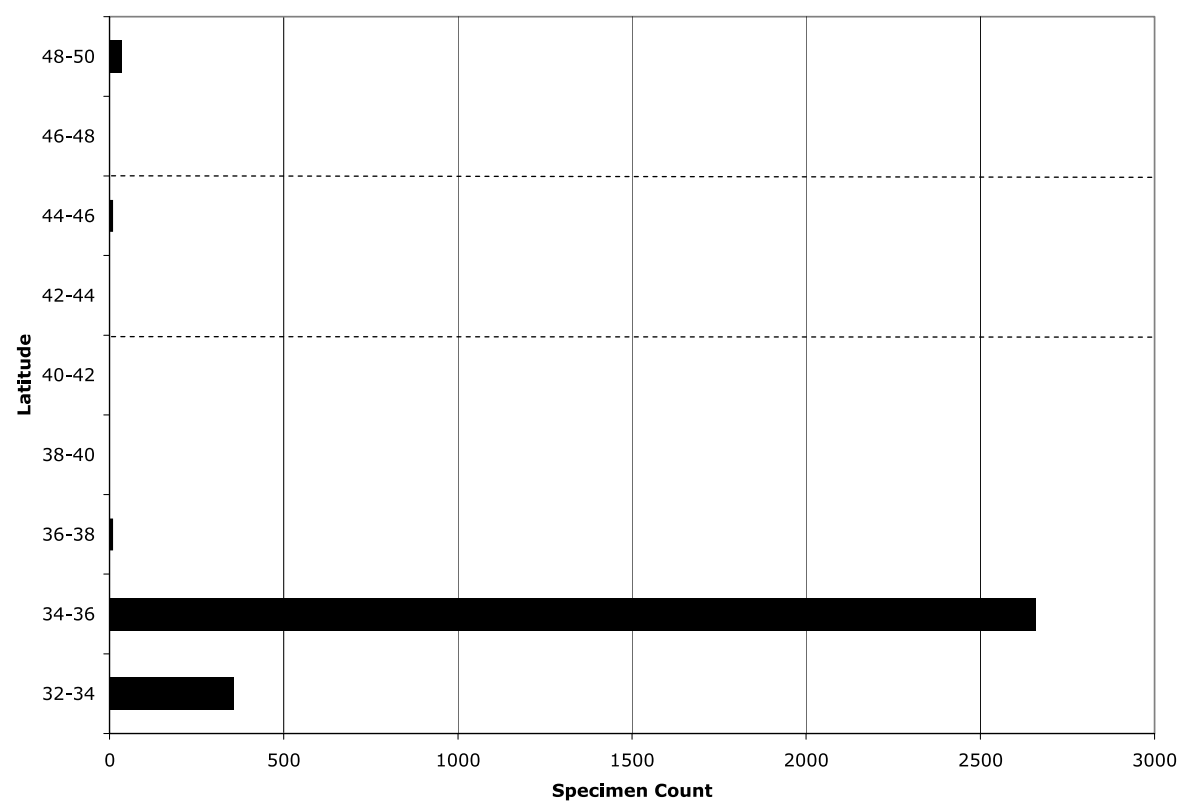

Figure 2. Plot of the total number of late Holocene (3500 cal B.P. to present) Guadalupe fur seal bones found in archaeological sites by approximate latitude in California (Table 1), Oregon (Lyon 1937:165, Moss et al. 2006), and Washington (Etnier 2002a). The dashed lines represent approximate location of California-Oregon border (bottom) and Oregon-Washington border (top).

by 10 in Santa Barbara County, and six each on Santa Cruz Island and in San Diego County.

The highest density of sites and individuals occurs on the Channel Islands and southern parts of the mainland, with the density declining north of Point Conception and none currently identified in California north of San Mateo County. Figure 2 presents the total specimen count for all late Holocene $(3500 \mathrm{cal}$ B.P. [calendar years before present, where present $=1950$ ] to present) samples broken up by approximate latitude. More than $98 \%$ of the specimens come from south of $36^{\circ}$ of latitude, demonstrating a much higher concentration of animals in southern California with smaller frequencies to the north.

The number of pinniped bones recovered from individual sites is governed by the extent of excavation, the intensity of pinniped hunting, bone preservation, recovery and analytical methods, and other variables. The largest count and MNI for a single site were from VEN-11 located at Point Mugu on the mainland, where Lyon (1937) reported 1,557 bones and $152 \mathrm{MNI}$. All other mainland sites have much lower counts and MNI-the next highest being 145 and most sites with fewer than 10. For the Channel Islands, the highest count comes from SCRI-240 on Santa Cruz Island where 622 specimens from more than 66 animals have been identified (Walker, unpublished data, Colten 2002, Noah 2005) and SNI-11 on San Nicolas Island where 428 specimens and 104 individuals were identified (Bleitz 1993). This is 


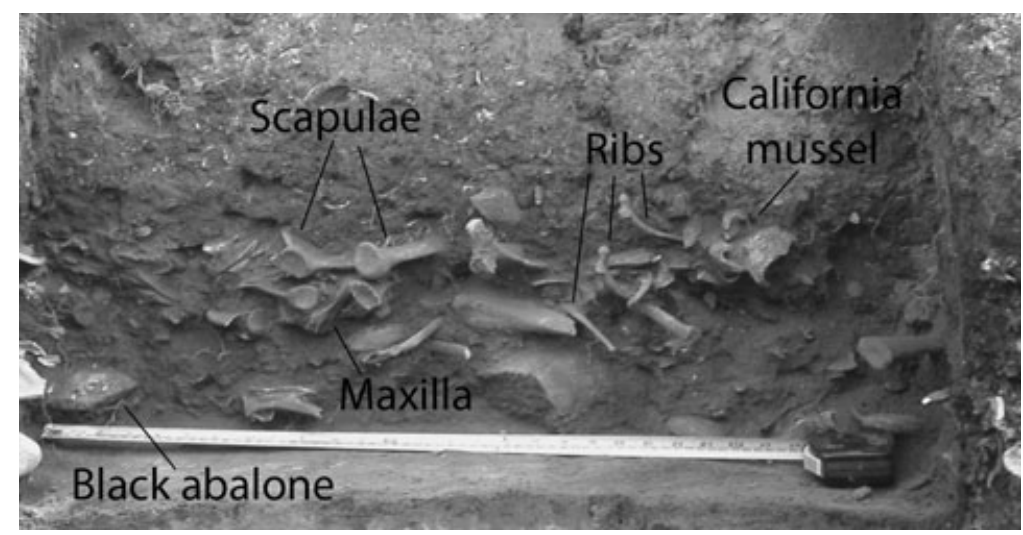

Figure 3. Closeup of a roughly $25 \mathrm{~cm}$ cross-section of an archaeological deposit rich in Guadalupe fur seal and other pinniped bones at CA-SMI-232, San Miguel Island (Photo by Todd Braje).

followed by SMI-528 with 85 specimens and SMI-232 with 84, both on San Miguel Island (Fig. 3; Walker et al. 2002, Braje and DeLong 2008 ${ }^{1}$ ).

A variety of other pinnipeds were identified in many of the assemblages reported in Table 1, including California sea lions, northern fur seals, northern elephant seals, Steller sea lions (Eumetopias jubatus), and harbor seals, as well as sea otters (Enhydra lutris). At many of these sites, Guadalupe fur seal remains are relatively rare with just a few identified, particularly at mainland sites. However, at sites on the Channel Islands and at VEN-11 on the Ventura County mainland, Guadalupe fur seals are often the most abundant pinniped. These include SNI-11 on San Nicolas, SCAI-CC on Santa Catalina, SCRI-191, -192, -240, and -330 on Santa Cruz, SRI-2 on Santa Rosa, and SMI-163, $-232,-481,-528$, and -602 on San Miguel where Guadalupe fur seals contributed $40 \%-80 \%$ of the pinniped bones.

Chronological data for many of the specimens in our study are limited by a variety of factors, including small numbers of radiocarbon dates available for some sites, insufficient reporting of data, and site disturbances. California mainland sites are often heavily affected by bioturbation and historical disturbances that have mixed deposits of different ages. These problems are generally minimized on the Channel Islands. The oldest specimens in the sample date to the early Holocene $(\sim 11,000$ to 7500 cal B.P.), including two bones reported by Garlinghouse (2000) from SCLI-43 on San Clemente Island and a single specimen from SDI-6010 in San Diego County associated with several dates between about 8000 and 7200 cal B.P. Specimens from SMI-1, SNI-11, and SCA-17 on the Channel Islands and SDI-10728a and MNT391 on the mainland may also date to the early or middle (7500 to 3500 cal B.P.) Holocene, but these sites also contain younger components. Most of the Guadalupe fur seal remains come from sites with components dating to the late Holocene

\footnotetext{
${ }^{1}$ Braje, T. J., and R. L. DeLong. 2008. Ancient sea mammal exploitation on the south Coast of San Miguel Island. In Proceedings of the Seventh California Islands Symposium. (unpublished).
} 
( $n>45$ ), with the highest concentration of bones coming from sites dated to the last 2,500-1,500 yr (e.g., SMI-232, -481, -528, -602, and VEN-11). The abundance of Guadalupe fur seals in late Holocene archaeological sites is in part related to sampling, since younger sites tend to be larger, denser, and better preserved than older sites. However, the late Holocene development of the plank canoe (tomol), a seaworthy form of watercraft used in parts of southern California, may have facilitated taking animals from offshore rocks, caves, the water, and other more difficult to access areas (Kennett 2005, Rick 2007).

Age and sex data were rarely reported, with the best data coming from sites on San Miguel (SMI-232, -481, -525, and -528), Santa Cruz (SCRI-240), and San Clemente (SCLI-43) islands and three sites on the Santa Barbara and Ventura County mainland (SBA-72, -73, and VEN-11). The archaeological samples are all dominated by adult or subadult females, with some juveniles and small numbers of pups ( $<1 \mathrm{yr}$ old). At SMI-232, 53 adults, 9 subadults, 16 juveniles, and 6 pups, with 53 females and 5 males were identified (Braje and DeLong 2008 ${ }^{1}$ ). Similarly, SMI-481 produced 37 adults or subadults, 2 juveniles, 40 females, and 2 males (Rick 2007). Eighty-five Guadalupe fur seal bones dominated by adult females and some immature males and females were present at SMI-528 (Walker et al. 2002). Although the samples are relatively small, Walker (1978, Walker and Craig 1979, Walker and Snethkamp 1984) reported Guadalupe fur seals from SMI-525, -492, -485, -261, and -504 that were dominated by females and included adults, subadults, and immature specimens. Walker (unpublished data) also identified the remains of 66 Guadalupe fur seals at SCRI-240, all of which were from adult females. At SCLI-43, Porcasi et al. (2000:213) identified 39 adult and 18 juvenile Guadalupe fur seals. They also indicated that mostly female and some neonate and fetal material suggest a pinniped rookery may have been nearby, though they did not specify the exact species associated with these remains (Porcasi et al. 2000:215). On the mainland, SBA-72 and -73 contain 38 bones, with juveniles, adults, and a few pups (Erlandson et al. 2008). Finally, at VEN-11 Lyon (1937) reported 1,337 adult females, 24 adult males, and 190 juveniles.

Determining the presence of a rookery using archaeological data requires the remains of pre-weaned pups, usually based on the estimated age of skeletal elements, and ideally adult male and female remains (Lyman 1988, Etnier 2002b). The abundance of female Guadalupe fur seal remains in California archaeological sites is consistent with the harvest of a breeding population of reproductive females that alternate time ashore for nursing pups and marine feeding for 8-10 mo of each year (Rice et al. 1965, Pierson 1987). Because adult Guadalupe fur seal females reproduce annually, most females of reproductive age would visit rookeries. While it remains possible that Guadalupe fur seals were breeding on the Channel Islands (see also Repenning et al. 1971:26), the dearth of pups, males, and definitive evidence for pre-weaned pups makes it impossible to determine if rookeries were present on the Channel Islands or elsewhere in California at this time.

Guadalupe fur seals and other pinnipeds may have been hunted or scavenged by Native Americans on land or at sea. A variety of hunting technologies have been identified in the region, including a distinctive type of stone projectile called Channel 
Islands Barbed (a.k.a Arena) points that date between about 10,000-8,000 yr ago and may have been used to hunt sea mammals (Erlandson and Braje 2007). Unfortunately, few of these have been found in clear association with marine mammal or other faunal remains. Other projectile points from across the Holocene may have also been used to hunt Guadalupe fur seals and other pinnipeds, and some individuals could have been clubbed while hauled out. As noted earlier, the plank canoe, thought to be developed around 1,500 yr ago, roughly corresponds with significant increases in Guadalupe fur seal and other pinniped remains, suggesting that people may have intensified efforts to acquire these animals from offshore rocks, caves, and the water (Kennett 2005, Rick 2007, Braje and DeLong 2008 ${ }^{1}$ ).

Several researchers have suggested that Guadalupe fur seal abundance in California and more northerly waters may be influenced by El Niño, with animals moving northward following warmer El Niño conditions (Hanni et al. 1997, Melin and DeLong 1999, Etnier 2002a). A single pup born on San Miguel Island in 1997 occurred during an El Niño year (Melin and DeLong 1999) and strandings in northern California are also correlated with El Niño events (Hanni et al. 1997). Most of the Guadalupe fur seals in our database date to the last 4,000 yr, a time when El Niño frequency was thought to increase (Kennett et al. 2007), suggesting a possible correlation between the prehistoric abundance of Guadalupe fur seals in California and El Niño. Modest numbers of Guadalupe fur seal remains also occur during the middle Holocene when the frequency of El Niño events may have been reduced (see Kennett et al. 2007). The small number of specimens from the California mainland north of Point Conception may be from animals that stranded during El Niños. However, it remains possible that Guadalupe fur seals in prehistoric southern California, were not as tightly correlated with El Niño, especially if breeding Guadalupe fur seal populations were considerably larger and more geographically dispersed than today. Stable isotope analyses could help determine how strongly the role of El Niño influenced ancient Guadalupe fur seal abundance and ecology.

Archaeological data indicate that Guadalupe fur seals were considerably more common in California, especially south of Point Conception, than they are today. The abundance of Guadalupe fur seals in southern California archaeological sites contrasts with the modern abundance of northern elephant seals, northern fur seals, and to a lesser extent California sea lions. The significant growth of Guadalupe fur seal populations over the last three decades, including recent strandings in northern California, Oregon, and Washington suggests that Guadalupe fur seals may be moving towards a distribution more consistent with their Holocene distribution, especially the last 3,500 yr. Based on the archaeological data, as the population of Guadalupe fur seals continues to grow in Mexico, they should become resident on the Channel Islands and frequent visitors at other hauling areas south of about $36^{\circ}$ of latitude, with animals present to the north, but probably in smaller numbers. Our analysis underscores the potential of archaeological data to help understand the historical ecology, biogeography, natural history, and management of pinnipeds and other marine organisms around the world (see Walker and Craig 1979, Lyman 1988, 
Etnier 2002a, Hildebrandt and Jones 2002, Moss et al. 2006, Braje and DeLong $\left.2008^{1}\right)$.

\section{ACKNOWLEDGMENTS}

We thank Channel Islands National Park for supporting our research. Ann Huston, Kelly Minas, Ian Williams, Mark Senning, and Steve Schwartz have been instrumental in providing logistical and other support for our work. Finally, we thank Daryl Boness, Kathryn Ono, R. Lee Lyman, and two anonymous reviewers for comments that substantially improved this manuscript.

\section{Literature Cited}

Bartholomew, G. A. 1950. A male Guadalupe fur seal on San Nicolas Island, California. Journal of Mammalogy 30:175-180.

BiCKFORD, V., AND P. MARTZ. 1980. Test excavations at Cottonwood Creek, Catalina Island, California. Pacific Coast Archaeological Society Quarterly 16:106-124.

BLEITZ, D. E. 1993. The prehistoric exploitation of marine mammals and birds at San Nicolas Island, California. Pages 519-536 in F.G. Hochberg, ed. Third California Islands symposium: Recent advances in research on the California Islands. Santa Barbara Museum of Natural History, Santa Barbara, CA.

Cairns, K. M., And J. H. Altschul. 1993. Chapter 9: Faunal analysis. Pages 131-149 in R. Vanderpot, J. H. Altschul and D. R. Grenda, eds. Whelan Lake (CA-SDI-6010): A La Jollan campsite on the lower San Luis Rey River, San Diego County, California. Statistical Research Technical Series No. 40, Tucson, AZ.

Carretta, J. V., K. A. Forney, M. M. Muto, J. Barlow, J. Baker, B. Hanson and M. S. LOWRY. 2007. U.S. Pacific marine mammal stock assessments: 2007. U.S. Department of Commerce. NOAA Technical Memorandum NOAA-TM-NMFS-SWFSC-398.

CARTIER, R. R. 1993. The Saunders site: MNT-391, a littoral site of the early period. Scotts Valley Historical Society Monograph 1. Scotts Valley, CA.

Colten, R. H. 2002. Prehistoric marine mammal hunting in context: Two western North American examples. International Journal of Osteoarchaeology 12:12-22.

DeLong, R. L., And S. R. Melin. 2002. Thirty years of pinniped research at San Miguel Island. Pages 401-406 in D. Browne, K. Mitchell and H. Chaney, eds. Proceedings of the fifth California Islands symposium. Santa Barbara Museum of Natural History, Santa Barbara, CA.

Dietz, S. A., W. R. Hildebrandt AND T. L. Jones. 1988. Archaeological investigations at Elkhorn Slough: CA-MNT-229, a Middle period site on the central California coast. Papers in Northern California Anthropology 3. Northern California Anthropological Research Group, Berkeley, CA.

ERlandson, J. M., AND T. J. BRAJE. 2007. Early maritime technology on California's San Miguel Island: Arena points from CA-SMI-575-NE. Current Research in the Pleistocene 24:85-86.

ERlandson, J. M., T. C. Rick and R. L. Vellanoweth. 2008. A canyon through time: The archaeology, history, and ecology of the Tecolote Canyon Region, Santa Barbara County, California. University of Utah Press, Salt Lake City, UT.

ETNier, M. A. 2002a. Occurrences of Guadalupe fur seals (Arctocephalus townsendi) on the Washington Coast over the past 500 years. Marine Mammal Science 18:551-557.

Etnier, M. A. 2002b. The effects of human hunting on northern fur seal (Callorbinus ursinus) migration and breeding distributions in the Late Holocene. Ph.D. dissertation, University of Washington, Seattle, WA. 410 pp. 
Gallo-Reynoso, J. P. 1994. Factors affecting the population status of Guadalupe fur seals, (Arctocephalus townsendi) at Isla de Guadalupe, Baja California, Mexico. Ph.D. dissertation, University of California, Santa Cruz, CA. 193 pp.

Gallo-reynoso, J. P., B. J. Le Boeuf, A. L. Figueroa-carranza and M. O. MaravillaCHÁvez. 2005. Los pinnípedos de Isla Guadalupe. Pages 170-201 in K. Santos del Prado and E. Peters, eds. Isla Guadalupe, restauración y conservación. Instituto Nacional de Ecología, Mexico.

GARLINGHOUSE, T. 2000. Human responses to insularity: The intensification of a marine oriented economy on San Clemente Island. Ph.D. dissertation, University of California, Davis, CA. 268 pp.

GOLDBERG, C. F. 1993. Stable carbon and nitrogen isotope analysis and dietary reconstruction in southern California. Ph.D. dissertation, University of California, Los Angeles, CA. $233 \mathrm{pp}$.

Grayson, D. K. 1984. Quantitative zooarchaeology. Academic Press, Orlando, FL.

Hanni, K. D., D. J. Long, R. E. Jones, P. Pyle and L. E. Morgan. 1997. Sightings and strandings of Guadalupe fur seals in central and northern California, 1988-1995. Journal of Mammalogy 78:684-690.

HildebrandT, W., AND T. L. Jones. 2002. Depletion of prehistoric pinniped populations along the California and Oregon coasts: Were humans the cause? Pages 72-110 in C. Kay and R. T. Simmons, eds. Wilderness and political ecology: Aboriginal influences and the original state of nature. University of Utah Press, Salt Lake City, UT.

HubBS, C. L. 1956. Back from oblivion. Guadalupe fur seal: Still a living species. Pacific Discovery 9:14-21.

Hudson, J. 1993a. Appendix C: analysis of vertebrate remains from SBA-27. Pages C1-26 in L. J. Santoro, A. G. Toren and T. Hazeltine, eds. Final cultural resource phase II study: Harbor View Inn, 28 West Cabrillo Boulevard, Santa Barbara, California 93101. Ogden Environmental and Energy Services, Santa Barbara. Report of the Central Coast Information Center.

Hudson, J. 1993b. Appendix C: Non-fish vertebrate remains from SBA-224 and SBA-225 Vandenberg AFB, California. Pages C-1-22 in Final report archaeological survey and evaluation Purisima Point sites SBA-224 and SBA-225 Vandenberg Air Force Base Santa Barbara County, California. Chambers Group and Scientific Applications International. National Technical Information Services, Springfield, VA.

Huey, L. 1930. Past and present status of the northern elephant seal with a note on the Guadalupe fur seal. Journal of Mammalogy 11:188-194.

Hylkema, M. G. 2002. Tidal marsh, oak woodland, and cultural florescence in the southern San Francisco Bay Region. Pages 233-262 in J. M. Erlandson and T. L. Jones, eds. Catalysts to complexity: Late Holocene societies of the California coast. Cotsen Institute of Archaeology, University of California, Los Angeles, CA.

Jones, T. L., AND J. Ferneau. 2002. De-intensification along the central Coast. Pages 204231 in J. M. Erlandson and T. L. Jones, eds. Catalysts to complexity: Late Holocene societies of the California coast. Cotsen Institute of Archaeology, University of California, Los Angeles, CA.

Jones, T. L., T. M. Van Bueren, S. Grantham, J. Huddleson and T. Fung. 1996. Archaeological test excavations for the Castroville Bypass Project, Monterey County, California. Office of Cultural Studies, California Department of Transportation. Report of the Northwest Archaeological Information Center.

Jones, T. L., AND G. WAUGH. 1997. Climatic consequences or population pragmatism?: A middle Holocene prehistory of the central California coast. Pages 111128 in J. M. Erlandson and M. A. Glassow, eds. Archaeology of the California coast during the middle Holocene. Institute of Archaeology, University of California, Los Angeles, CA.

Jones, T. L., J. F. Porcasi, J. Gaeta and B. F. Codding. 2008. The Diablo Canyon fauna: A coarse-grained record of trans-Holocene foraging from the central California mainland coast. American Antiquity 73:289-316. 
KennetT, D. J. 2005. The Island Chumash: Behavioral ecology of a maritime society. University of California Press, Berkeley, CA.

Kennett, D. J., J. P. Kennett, J. M. ERLandson and K. G. Cannariato. 2007. Human responses to middle Holocene climate change on California's Channel Islands. Quaternary Science Reviews 26:351-367.

LAGENWALTER, P. E. II. n.d. Appendix E: The Mescalitan Island site III (CA-SBA-46) archaeofauna exclusive of fish and birds. Pages E1-14 in SBA-46 test program (Volume III), scientific resource surveys. Report of the Central Coast Information Center.

Lagenwalter, P. E. II. 1981. Excavations at ORA-193, Newport Bay, California. Appendix 3 , the reptiles and mammals from ORA-193. Pacific Coast Archaeological Society Quarterly 17:100-118.

LAGENWAlteR, P. E. II. 1991. Vertebrate animal remains (Section 4.7). Pages 164-182 in R. D. Mason, B. A. Brechbiel, M. L. Peterson, C. A. Singer, P. E. Langenwalter II, R. O. Gibson, T. Morgan and G. S. Hurd, eds. Newport Coast archaeological project: Results of data recovery at the Wishbone Hill sites, CA-ORA-339, CA-ORA-340, CA-ORA-928, CA-ORA-929. The Keith Companies, Costa Mesa, CA.

Lebow, C., R. L. McKim, D. R. Harro, A. M. Munns and C. Denardo. 2007. Littoral adaptations throughout the Holocene: Archaeological investigations at the Honda Beach site (CA-SBA-530), Vandenberg Air Force Base, Santa Barbara County, California. Applied Earthworks, Lompoc (CA). Report of the Central Coast Information Center.

Lyman, R. L. 1988. Zoogeography of Oregon coast marine mammals: The last 3000 years. Marine Mammal Science 4:247-264.

Lyman, R. L. 2002. Taxonomic identification of zooarchaeological remains. The Review of Archaeology 23(2):13-20.

Lyman, R. L. 2008. Quantitative paleozoology. Cambridge University Press, Cambridge, U.K.

LyON, G. M. 1937. Pinnipeds and a sea otter from the Point Mugu shellmound of California. Publications of the University of California at Los Angeles in Biological Sciences 1:133168.

MartZ, P. C. 2005. Prehistoric subsistence and settlement on San Nicolas Island. Pages 6582 in D. Garcelon and C. Schwemm, eds. Proceedings of the sixth California Islands symposium. National Park Service Technical Publication CHIS-05-01, Institute for Wildlife Studies, Arcata, CA.

McKim, R. L., C. G. Lebow, D. L. Harro and A. M. Munns. 2007. CA-SBA-212: Sea mammal hunting and other Late Holocene littoral adaptations. Vandenberg Air Force Base, Santa Barbara County, California. Lompoc (CA): Applied Earthworks, Inc. Report of the Central Coast Information Center.

Melin, S. R., AND R. L. DeLong. 1999. Observations of a Guadalupe fur seal (Arctocephalus townsendi) female and pup at San Miguel Island, California. Marine Mammal Science 15:885-888.

Merriam, C. H. 1897. A new fur-seal or sea-bear (Arctocephalus townsendi) from Guadalupe Island, off Lower California. Proceedings of the Biological Society of Washington 11:175178.

Michals, L. 1993. Mammal, bird, amphibian, and reptile remains. Pages 127-140 in J. Erlandson and J. Gerber, eds. Archaeological investigations at CA-SBA-1731: A transitional Middle-to-Late period site on the Santa Barbara Channel. Dames and Moore, Santa Barbara, CA.

Moore, J., B. Bowser, P. Lambert and L. Sehgal. 1988. Faunal remains. Pages 88-102 in J. D. Moore, A. I. Gerstle, P. Lambert, J. Moriarty III, B. B. Bowser, S. DayMoriarty and L. Sehgal, eds. Archaeological investigations at CA-SBA-1541: Prehistoric settlement, subsistence, and economy. Painted Cave Archaeological Associates, Santa Barbara. Report of the South Coast Information Center.

Moss, M. L., D. Y. Lang, S. D. Newsome, C. F. Speller, I. Mckechnie, A. D. Mcmillan, R. J. Losey AND P. L. Koch. 2006. Historical ecology and biogeography of North Pacific 
pinnipeds: Isotopes and ancient DNA from three archaeological assemblages. Journal of Island and Coastal Archaeology 1:165-190.

NoAH, A. C. 2005. Household economies: The role of animals in a Historic period chiefdom on the California coast. Ph.D. dissertation, University of California, Los Angeles, CA. $356 \mathrm{pp}$.

Peterson, R. S., C. L. Hubbs, R. L. Gentry and R. L. DeLong. 1968. The Guadalupe fur seal: habitat, behavior, population size, and field identification. Journal of Mammalogy 49:665-675.

Pierson, M. O. 1987. Breeding behavior of Guadalupe fur seals, Arctocephalus townsendi. Pages 83-94 in J. P. Croxall and R. L. Gentry, eds. Status, biology and ecology of fur seals. NOAA Technical Report, NMFS 51.

PorCASI, J. F. 2002. Updating prehistoric maritime subsistence at Little Harbor, Santa Catalina Island, California. Pages 580-589 in D. Browne, K. Mitchell and H. Chaney, eds. Proceedings of the fifth California Islands symposium. Santa Barbara Museum of Natural History, Santa Barbara, CA.

PorCASI, J. F. 2006. Non-piscine vertebrate fauna from CA-MNT-831, Pacific Grove, Monterey County, California. Pages 153-172 in G. S. Breschini and T. Haversat, eds. Report on archaeological monitoring for a portion of CA-MNT-831, Pacific Grove, Monterey County, California. Archaeological Consulting, Salinas, California. Report of the Northwest Archaeological Information Center.

Porcasi, J. F., T. L. Jones AND L. M. RaAB. 2000. Trans-Holocene marine mammal exploitation on San Clemente Island: A tragedy of the commons revisited. Journal of Anthropological Archaeology 19:200-220.

Pyle, P., D. J. Long, J. Schonewald, R. E. Jones and J. Roletto. 2001. Historical and recent colonization of South Farallon Islands, California by northern fur seals (Callorbinus ursinus). Marine Mammal Science 17:397-402.

Repenning, C. A., R. S. Peterson And C. L. Hubbs. 1971. Contributions to the systematics of the sourthern fur seals, with particular reference to the Juan Fernandez and Guadalupe species. Antarctic Research Series 18:1-33.

Rice, D. W., K. W. KenYon And D. B. LluCh. 1965. Pinniped populations at Islas Guadalupe, San Benito, and Cedros, Baja California, in 1965. Transactions of the San Diego Society of Natural History 14(7):73-84.

Rick, T. C. 2004. Daily activities, community dynamics, and historical ecology on California's Northern Channel Islands. Ph.D. dissertation, University of Oregon, Eugene, OR. 516 pp.

RicK, T. C. 2007. The archaeology and historical ecology of late Holocene San Miguel Island. Cotsen Institute of Archaeology, University of California, Los Angeles, CA.

RidDell, R. A. 1955. Archaeological excavations on the Farallon Islands, California. Report of the University of California Archaeological Survey 32:1-18.

SANDEFUR, E. 1978. Appendix 3: Anacapa Island faunal analysis. Pages 187-203 in C. Rozaire, ed. A report on the archaeological investigations of three California Channel Islands: Santa Barbara, Anacapa, and San Miguel. Report of the Department of Anthropology.

SimONS, D. D. 1979. The vertebrate fauna from Ventura-100: Reptiles, birds, and mammals. Pages 49-71 in G. J. West, ed. The archaeology of Ven-100. California Archaeological Reports No. 17. Report of the California Department of Parks and Recreation.

STARKS, E. C. 1922. Records of the capture of fur seals on land in Claifornia. California Fish Game 8:155-160.

Stewart, B. S., P. K. Yochem, R. L. DeLong and G. A. Antonelis. 1993. Trends in abundance and status of pinnipeds on the Southern California Channel Islands. Pages 501-516 in F. G. Hochberg, ed. Third California Islands symposium: Recent advances in research on the California Islands. Santa Barbara Museum of Natural History, Santa Barbara, CA.

WAKE, T. A. 1999. Temporal variation in vertebrate archaeofaunas from Camp Pendleton Marine Corps Base, San Diego County, California. Pacific Coast Archaeological Society Quarterly 35(4):45-64. 
WAKE, T. A. 2004. Archaeological Investigations at CA-LAN-49, an archaeological site in the uplands of Leo Carillo State Park, Los Angeles County, California. Report of the California State Parks Southern Service Center, San Diego, California, 71 pp.

WALKER, P. L. 1978. An ethnozoological analysis of faunal remains from four Santa Barbara Channel Island archaeological sites. Report of the Channel Islands National Park.

Walker, P. L., AND S. Craig. 1979. Archaeological evidence concerning the prehistoric abundance of sea mammals at Point Bennett, San Miguel Island. California Fish and Game 65:50-54.

Walker, P. L., AND P. E. SnethKamp. 1984. Archaeological investigations on San Miguel Island-1982: Prehistoric adaptations to the marine environment. Report of the Central Coast Information Center.

Walker, P. L., D. J. Kennett, T. Jones and R. L. DeLong. 2002. Archaeological investigations of the Point Bennett pinniped rookery on San Miguel Island. Pages 628-632 in D. Browne, K. Mitchell and H. Chaney, eds. Proceedings of the fifth California Islands symposium. Santa Barbara Museum of Natural History, Santa Barbara, CA.

Weber, D. S., B. S. Stewart and N. Lehman. 2004. Genetic consequences of a severe population bottleneck in the Guadalupe fur seal (Arctocephalus townsendi). Journal of Heredity 95:144-153.

Wedgeforth, H. M. 1928. The Guadalupe fur seal (Arctocephalus townsendi). Zoonooz, San Diego Zoological Society 3:4-9. 